\title{
10. DIAGENETIC REACTIONS IN LEG 104 SEDIMENTS INFERRED FROM ISOTOPE AND MAJOR ELEMENT CHEMISTRY OF INTERSTITIAL WATERS1
}

\author{
Per Aagaard, ${ }^{2}$ Per Kristian Egeberg, ${ }^{2}$ and P. Craig Smalley ${ }^{3}$
}

\begin{abstract}
The variations in major elements and isotope composition $\left({ }^{87} \mathrm{Sr} /{ }^{86} \mathrm{Sr}, \delta^{18} \mathrm{O}, \delta \mathrm{D}\right)$ of interstitial waters in Leg 104 sediments is most probably caused by the alteration of volcanic matter. A reaction scheme where volcanic glass reacts with pore-water magnesium and potassium to form trioctahedral smectite, phillipsite, and chert is proposed. Model calculations demonstrate that the pore waters may evolve their negative $\delta^{18} \mathrm{O}$ signatures without recourse to unreasonably large amounts of volcanic detritus or external sources.
\end{abstract}

\section{INTRODUCTION}

Interstitial water samples extracted from sediment cores from Holes $642 \mathrm{C}$ and D, 643A, and 644A (see Introduction chapter to this volume for location and lithological description), have been analyzed with respect to strontium isotope ratio, stable isotopes of oxygen and hydrogen, and major elements. Previous studies on pore-water chemistry from nearby sediments (DSDP Leg 38, Gieskes et al., 1978) demonstrate consistent compositional variation with depth. These findings were confirmed during ODP Leg 104, and the Shipboard Scientific party concluded that the sediments on Site 642 and 643 had undergone substantial postburial, diagenetic changes (Eldholm, Thiede, Taylor, et al., 1987). The aim of this study was thus to apply the isotope data to decipher the diagenetic processes responsible for the compositional trends found in the pore waters.

\section{ANALYTICAL METHODS}

The interstitial waters were obtained by shipboard extraction using the procedure and equipment described by Manheim and Sayles (1974) and were received in sealed polyethylene capsules. They were stored in a refrigerator. Calcium, magnesium, potassium, and strontium contents were determined by standard atomic absorption technique, while silica was analyzed spectrophotometrically. The $\delta^{18} \mathrm{O}$ values of pore waters were determined using the $\mathrm{CO}_{2}$ equilibration method; $\delta \mathrm{D}$ by reduction on metallic zinc at $900^{\circ} \mathrm{C}$. Isotope analyses were performed on a Finnigan MAT 251 mass spectrometer. The results are reproducible to \pm $0.2 \%_{0}$ ( 2 sigma) for $\delta^{18} \mathrm{O}$ and $\pm 1 \%_{0}$ ( 2 sigma) for $\delta \mathrm{D}$. Values are reported relative to the SMOW scale. For ${ }^{87} \mathrm{Sr} /{ }^{86} \mathrm{Sr}$ isotope analysis, $\mathrm{Sr}$ was concentrated from pore-water samples using miniature ion-exchange columns. The strontium concentrates were analyzed on a Finnigan MAT 261 mass spectrometer in the static multicollector mode. ${ }^{87} \mathrm{Sr} /{ }^{86} \mathrm{Sr}$ ratios were normalized to ${ }^{86} \mathrm{Sr} /{ }^{88} \mathrm{Sr}=0.1194$. Measurements of the NBS 987 standard during the period of analysis averaged 0.710251 ( 2 sigma $0.000015, \mathrm{n}=11$ ).

\section{RESULTS}

The isotopic $\left({ }^{87} \mathrm{Sr} /{ }^{86} \mathrm{Sr}, \delta^{18} \mathrm{O}\right.$ and $\left.\delta \mathrm{D}\right)$ and chemical compositions of the interstitial waters are given in Table 1 , and the main depth variations are also depicted in Figures 1, 2, and 3. From Hole 644A only two pore-water samples were delivered; because they are closely spaced (124 and 145 mbsf), no depth trends can

\footnotetext{
${ }^{1}$ Eldholm, O., Thiede, J., Taylor, E., et al., 1989. Proc. ODP, Sci. Results, 104: College Station, TX (Ocean Drilling Program).

2 Department of Geology, University of Oslo, P.O. Box 1047 Blindern, N-0316 Oslo 3, Norway.

${ }^{3}$ Institute for Energy Technology, P.O. Box 40, Kjeller, N-2000, Norway.
}

be delineated. However, the strontium isotope ratios are close to those of contemporaneous seawater (DePaolo, 1986), indicating that very minor diagenetic changes have involved the solid constituents in these young hemipelagic sediments. The diagenesis of the organic constituents of the Site 644 cores is described in Shipboard Scientific Party, 1987c; Kvenvolden and McDonald, this volume; Kvenvolden et al., this volume; and Vuletich et al., this volume.

The interstitial waters of sediments from the two other Sites $(642,643)$ all exhibit a pronounced depth variation in the isotopic, as well as in the major element composition (compare Figs. 1, 2, and 3). The ${ }^{87} \mathrm{Sr} /{ }^{86} \mathrm{Sr}$ ratios are consistently lighter than contemporaneous seawater except for the uppermost meters of sediments. The deepest sample from Hole 642D has a strontium isotope ratio as low as 0.7078 . The oxygen stable isotope composition varies from seawater composition in the top sediments to $\delta^{18} \mathrm{O}$ values of -2 to -3 in the deepest samples. A corresponding decrease in $\delta \mathrm{D}$ values is also evident in Figure 2. Our own laboratory analyses of magnesium and calcium are consistent with the shipboard analyses data set (Shipboard Scientific Party, 1987a, b, c), and confirm the well established steady decrease in magnesium with depth and a corresponding increase in calcium (Fig. 3). We also paid much attention to the behavior of potassium; it decreases steadily downhole (Fig. 3), in covariance with magnesium.

\section{DISCUSSION}

\section{Sr Isotopes}

The strontium isotope data clearly indicate that substantial diagenetic solid-water relations have taken place in the sediments from Sites 642 and 643 . The pore water must have reacted with solid sources of light strontium; the most likely candidate would be dispersed volcanic detritus (Hawkesworth and Elderfield, 1987; Elderfield and Gieskes, 1982). The major part of the sediment sequence that was sampled for interstitial waters was from lithological Units II and III. In both Sites 642 and 643 (Shipboard Scientific Party, 1987 a, b), these sediments consist of siliceous muds and oozes interbedded with nannofossil oozes. Clay-sized and coarser clastics occur throughout, and only in Unit II are carbonate layers frequent. The carbonate components, however, do not appear to take any important part in the solid-water reactions. This is certainly the case for the sediments of Site 642, where the dissolved strontium is very low and increases very little with depth (compare Fig. 4). The carbonates in Hole 643A may have been slightly more involved in diagenetic reactions. This is indicated both by the higher concentra- 
Table 1. Summary of the analyses of ${ }^{87} \mathrm{Sr} /{ }^{86} \mathrm{Sr}, \delta^{18} \mathrm{O}, \delta \mathrm{D}$, and dissolved constituents of interstitial water from ODP Leg 104 sediment cores.

\begin{tabular}{|c|c|c|c|c|c|c|c|c|c|c|}
\hline Site & $\begin{array}{c}\text { Sample } \\
\text { no. }\end{array}$ & $\begin{array}{l}\text { Depth } \\
\text { (mbsf) }\end{array}$ & $\cdot 7 \mathrm{Sr} /{ }^{7} \mathrm{Sr}$ & $\begin{array}{l}8 \times 0 \\
(0 / 00)\end{array}$ & $\begin{array}{l}\delta D \\
(0 / 00)\end{array}$ & $\begin{array}{l}\mathrm{Mg} \\
(\mathrm{mM})\end{array}$ & $\begin{array}{c}\mathrm{Ca} \\
(\mathrm{mM})\end{array}$ & $\begin{array}{c}K \\
(m M)\end{array}$ & $\begin{array}{l}\mathrm{Sr} \\
(\mathrm{mK})\end{array}$ & $\begin{array}{l}\mathrm{SiO} 2(\mathrm{aq}) \\
(\mathrm{mM})\end{array}$ \\
\hline & 100 & 1.5 & 0.70921 & 0.2 & 1.8 & 58.8 & 12.5 & 22.3 & 0.051 & 0.10 \\
\hline & 101 & 1.5 & & & & 59.6 & 13.5 & 19.2 & 0.052 & 0.10 \\
\hline & 102 & 17.5 & & & & 51.0 & 11.2 & 18.7 & 0.054 & 0.15 \\
\hline & 103 & 17.5 & & 0.5 & 1.3 & 53.5 & 12.0 & 18.7 & 0.054 & 0.13 \\
\hline & 104 & 45.5 & 0.70886 & 0.4 & -0.2 & 46.9 & 14.7 & 16.9 & 0.050 & 0.13 \\
\hline & 105 & 59.5 & & & & 30.0 & 12.5 & 14.8 & 0.058 & 0.28 \\
\hline & 106 & 59.5 & 0.70858 & 0.2 & -1.0 & 41.1 & 19.5 & 17.9 & 0.059 & 0.27 \\
\hline \multirow[t]{10}{*}{642} & 107 & 92 & 0.70843 & -0.5 & 3.2 & 35.4 & 22.2 & 14.6 & 0.057 & 0.35 \\
\hline & 108 & 125 & & & & 33.7 & 30.4 & 12.0 & 0.059 & 0.43 \\
\hline & 109 & 125 & 0.70823 & -0.7 & -0.8 & 31.3 & 30.4 & 11.5 & 0.065 & 0.42 \\
\hline & 110 & 152.5 & & & & 28.0 & 38.7 & 17.6 & 0.070 & 0.43 \\
\hline & 111 & 152.5 & $0.70812-$ & -1.1 & -0.7 & 30.0 & 35.7 & 11.0 & 0.073 & 0.47 \\
\hline & 112 & 179 & 0.70798 & -1.5 & -6.3 & 21.8 & 39.2 & 9.5 & 0.134 & 0.68 \\
\hline & 113 & 216 & 0.70795 & -1.3 & -3.7 & 24.7 & 42.2 & 8.2 & 0.078 & 0.53 \\
\hline & 114 & 245 & 0.70789 & 0.3 & -4.1 & 24.7 & 48.7 & 8.2 & 0.068 & 0.60 \\
\hline & 115 & 274 & 0.70782 & -2.0 & -0.8 & 21.0 & 48.7 & 6.6 & 0.074 & 0.58 \\
\hline & 116 & 274 & & & & 21.4 & 54.9 & 7.9 & 0.079 & 0.57 \\
\hline \multirow[t]{5}{*}{ s. $v$. } & 117 & 0 & 0.70910 & 0.2 & 5.9 & 59.6 & 12.0 & 14.1 & 0.058 & 0.01 \\
\hline & 118 & 3 & 0.70911 & 1.3 & -1.5 & 52.2 & 12.5 & 11.8 & 0.088 & 0.07 \\
\hline & 119 & 58 & 0.70861 & 0.5 & 0.0 & 42.8 & 15.0 & 13.0 & 0.080 & 0.25 \\
\hline & 120 & 116 & 0.70851 & -1.4 & -1.7 & 41.1 & 18.7 & 11.5 & 0.102 & 0.47 \\
\hline & 121 & 145 & & & & 38.7 & 20.2 & 10.5 & 0.113 & 0.58 \\
\hline \multirow[t]{7}{*}{643} & 122 & 145 & 0.70847 & -1.2 & -3.1 & 39.1 & 20.2 & 10.2 & 0.110 & 0.50 \\
\hline & 123 & 173 & 0.70842 & -2.2 & -7.3 & 39.9 & 21.2 & 10.5 & 0.101 & 0.52 \\
\hline & 124 & 2 & & & & & & & & \\
\hline & 125 & 200 & 0.70826 & -2.6 & -4.3 & 41.1 & 22.7 & 12.8 & 0.080 & 0.52 \\
\hline & 126 & 260 & & & & & & & & \\
\hline & 127 & 260 & 0.70813 & -2.4 & -7.2 & 32.9 & 25.4 & 10.7 & 0.136 & 0.58 \\
\hline & 128 & 260 & & & & 37.0 & 21.7 & 9.7 & 0.136 & 0.68 \\
\hline \multirow[t]{2}{*}{ s. v. } & 129 & 0 & 0.70916 & 0.2 & 2.1 & & & 14.8 & 0.040 & 0.01 \\
\hline & 130 & 124 & 0.70914 & 3.7 & 1.7 & 55.9 & 2.6 & 20.5 & 0.104 & 0.27 \\
\hline \multirow[t]{3}{*}{644} & 131 & 124 & & & & 39.9 & 5.0 & 13.6 & 0.073 & 0.20 \\
\hline & 132 & 145 & & & & 36.6 & 4.2 & 14.3 & 0.070 & 0.27 \\
\hline & 133 & 145 & 0.70915 & -0.9 & 3.2 & 35.8 & 3.6 & 15.3 & 0.143 & 0.23 \\
\hline
\end{tabular}

tions of dissolved strontium (Fig. 4) as well as the smaller deviation from the ${ }^{87} \mathrm{Sr} /{ }^{86} \mathrm{Sr}$ curve of seawater (Fig. 1). Although other sources of strontium (as carbonates and siliciclastic detritus, Egeberg et al., in press b) by no means can be totally excluded, the main conclusion to be drawn from the strontium isotopes and dissolved strontium is the overwhelming effect of the reactions between volcanic detritus and the interstitial water.

\section{Stable Isotopes of Oxygen and Hydrogen}

The oxygen isotopes follow a similar evolutionary pattern as noted for the strontium isotopes (Fig. 5A). There is a steady shift in $\delta^{18} \mathrm{O}$ of the interstitial water toward lighter values with increasing depth. In the uppermost sediments values are close to that of seawater (about $0 \%$ ), while at 200-300 meters depth the range is between -2 to $-3 \%$. Similar shifts toward lighter values in deep-sea sediments have been attributed to low-temperature alteration of volcanic matter (Lawrence et al., 1975). The proposed solid reaction products were either authigenic clays (especially smectites) or zeolites. Two opposing mechanisms have been applied in the discussion about low-temperature alteration of volcanic matter. Perry et al. (1976) considered volcanic detritus within the sediments as the reacting solids, while Lawrence et al. (1975) considered the interaction of circulating water with the basaltic basement beneath the sediments and a subsequent diffusive (and/or advective) transport through the sedimentary column. The isotopic fractionation factor would normally be higher in the sediments because of lower temperatures, but in the early model calculations (Lawrence et al., 1975) this was outweighed by the assumed lower $\delta^{18} \mathrm{O}$ values of the basaltic basement $(+6 \%$ ) compared with $+10 \%$ of volcanic detritus. Lawrence and Gieskes (1981) favored the large-scale diffusive transport to and from the volcanic basement because: (a) unreasonably large quantities of volcanic detritus in the sediments had to react to produce the necessary shift in oxygen isotopes, and (b) the persistence of concentration profiles both in isotopes and major elements through the sediments. Egeberg et al. (in press a) argued that by considering the complete alteration process of sediment volcanic fragments to trioctahedral smectite, chert, and potassium zeolite, a larger oxygen isotope fractionation will only require the alteration of up to $5 \%$ of volcanic detritus. We would also argue from what is known about water circulation and cooling history of volcanic basement in general (Staudigel and Hart, 1985) and the specific case of the basement beneath the Vøring Plateau (LeHuray and Johnson, this volume), that thermally driven water circulation and alteration of the volcanic basement has not been active in the last 5 to $10 \mathrm{Ma}$.

Figure $5 \mathrm{~B}$, representing a standard $\delta \mathrm{D} / \delta^{18} \mathrm{O}$ plot, outlines a definite and interesting covariation between the isotopic fractionation of hydrogen and oxygen. The same correspondence was noted by Lawrence and Gieskes (1981), and they suggested several mechanisms to explain this behavior of the hydrogen iso- 
A

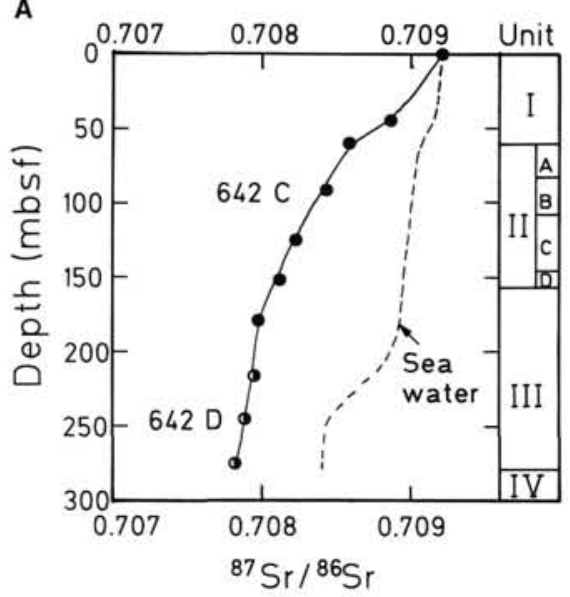

B

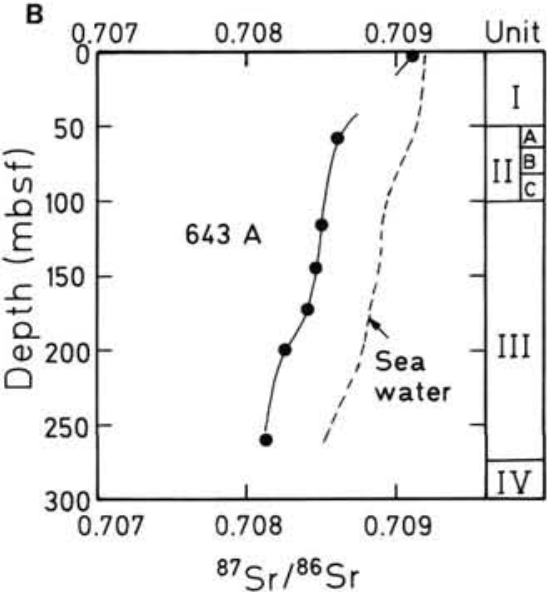

Figure 1. Variations of strontium isotope ratio in interstitial water from ODP Leg 104 sediments. A: Holes $642 \mathrm{C}$ and 642D, B: Hole 643A. Values for contemporaneous seawater are shown for comparison, based on DePaolo (1986) and the dating summary of Leg 104 cores (Goll this volume).

A

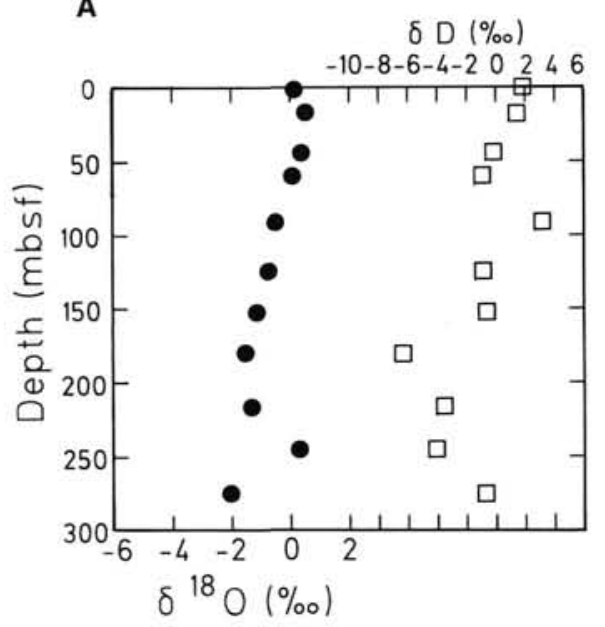

B

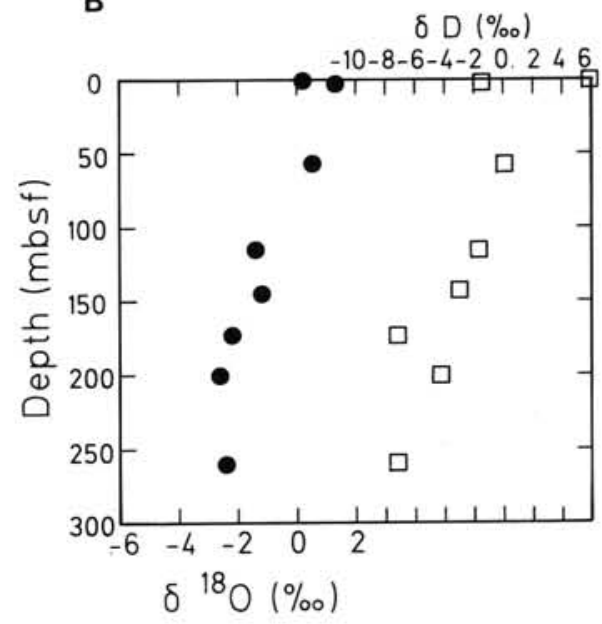

Figure 2. Isotopic composition of oxygen (dots) and hydrogen (squares) in interstitial waters from ODP Leg 104 sediments. A: Holes $642 \mathrm{C}$ and 642D, B: Hole 643A.

A

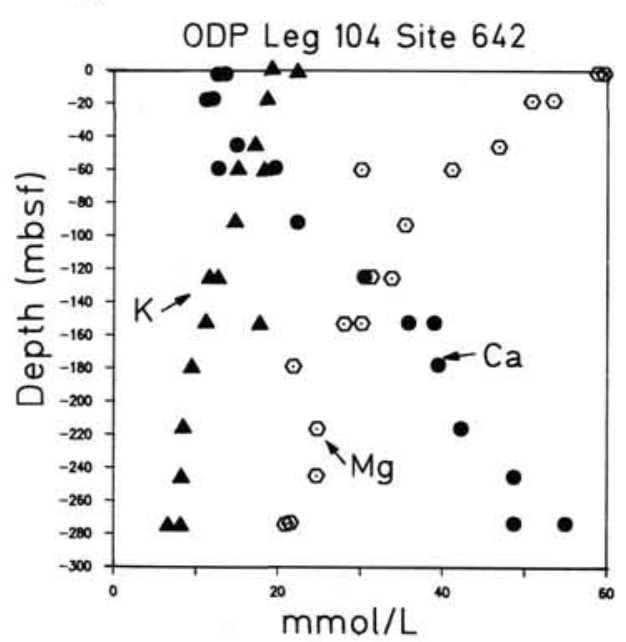

B

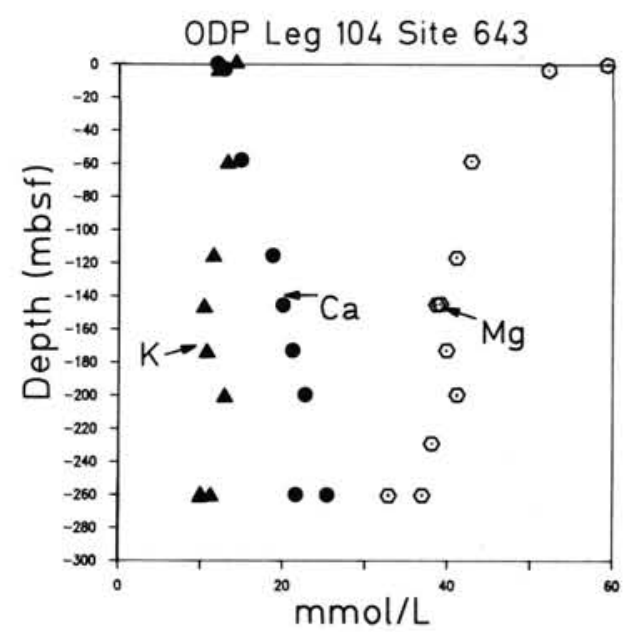

Figure 3. Compositional variation of dissolved magnesium, calcium, and potassium in interstitial waters from ODP Leg 104 sediments. A: Holes 642C and 642D, B: Hole 643A. 


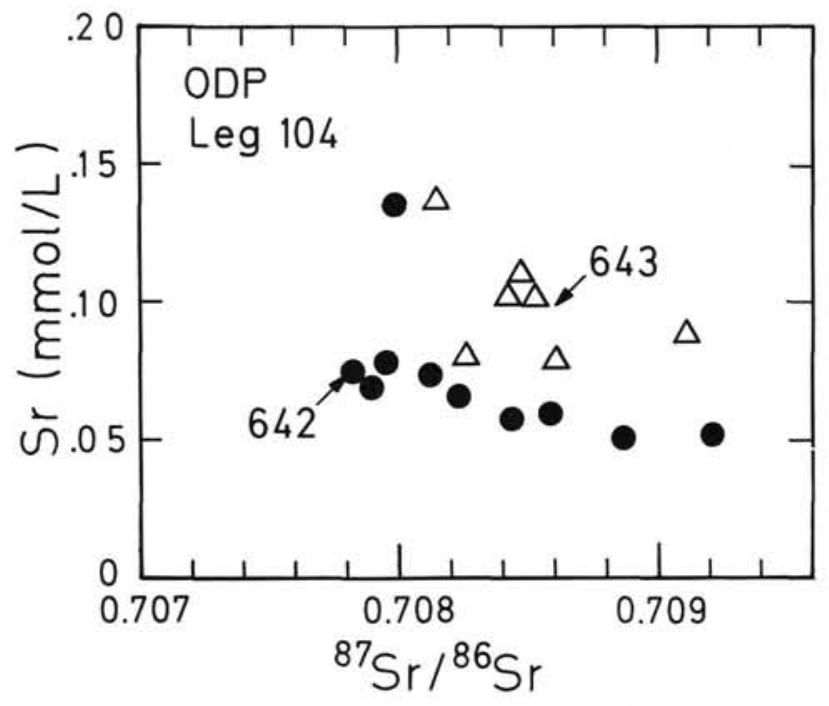

Figure 4. Dissolved strontium as a function of the ${ }^{87} \mathrm{Sr} /{ }^{86} \mathrm{Sr}$ ratios of interstitial water. The low values of dissolved strontium combined with isotopically light strontium suggest volcanic glass as the strontium source.

topes: (a) isotopic fractionation between pore-water and authigenic smectite (structural $\mathrm{OH}$-groups and interlayer water, (b) hydrogen isotope shifts in paleo-oceanwater, and (c) membrane squeezing effects. However, according to Lawrence and Gieskes (1981), none of these mechanisms explain the large shift toward lighter hydrogen isotopes.

\section{Major Elements and Reaction Stoichiometry}

The covariation between dissolved calcium, magnesium, and potassium is depicted in Figure 6. The calcium and magnesium data are approximately linearly correlated with a $\Delta \mathrm{Ca} / \Delta \mathrm{Mg}$ slope close to -1.0 , while the potassium vs. magnesium define a $\Delta \mathrm{K} / \Delta \mathrm{Mg}$ slope close to $1: 3$. This covariance places certain constraints with respect to the overall stoichiometry of the diagenetic reaction. Dissolved magnesium and potassium behave as reactants in the molar ratio 3 to 1 , while one mole of dissolved calcium is produced as one mole of magnesium is consumed by the reaction. This is in general agreement with the reaction scheme proposed by Egeberg et al. (in press a) to account for the shifts in oxygen isotopes observed in Leg 113 interstitial waters.

Regarding the candidates for the solid reactants, the Neogene and Quaternary sediments of Sites 642 and 643 contain considerable volcanic detritus. Frequent discrete ash layers and also more disseminated ashes occur throughout the sequence (Shipboard Scientific Party, 1987 a, b; Bitschene et al., this volume; Desprairies et al., this volume). The composition of the ash layers have been studied by Bitscheneyet al. (this volume) and Desprairies et al. (this volume). According to Desprairies et al. (this volume), the ash layers can be grouped into more homogeneous and heterogeneous ones with regard to the volcanic glass content. The homogeneous layers consist mostly of fresh rhyolitic glass, but also contain variable amounts of more basic glass shards. The heterogeneous layers, however, show bimodal acidic-basic frequency distribution of the glass shards, with the components of the tholeiitic differentiation trend. Smectite was a common alteration product from both acidic and basic glasses. Several reaction schemes can be constructed for the alteration of volcanic glass within the constraints given by the reaction coefficients of dissolved potassium, magnesium, and calcium, depending on the composition of the product minerals. We have in this study used the average composition of calc-al-
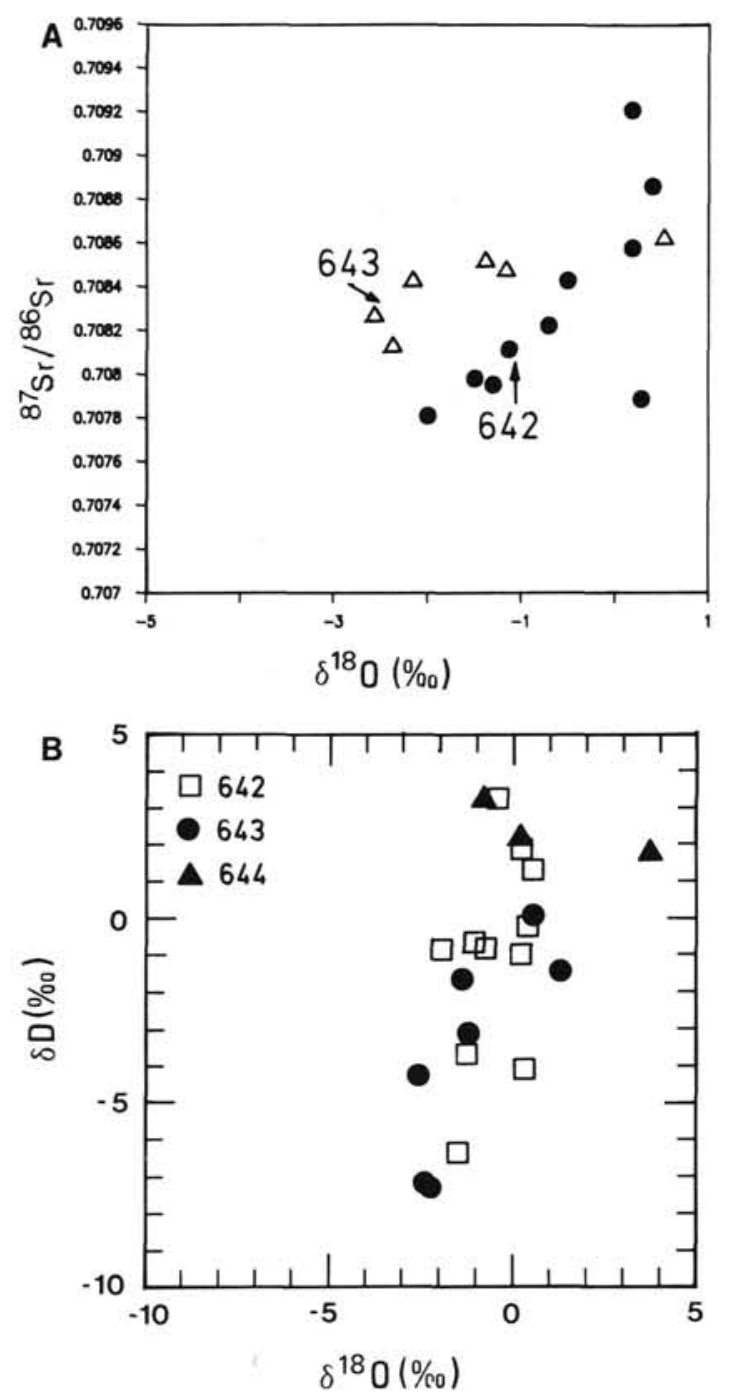

Figure 5. A: ${ }^{87} \mathrm{Sr} /{ }^{86} \mathrm{Sr}$ ratio vs. $\delta^{18} \mathrm{O}$ in interstitial waters in ODP Leg 104 sediments. Note the correlation between the shifts in isotopic composition. B: Isotopic composition of oxygen and hydrogen of interstitial waters in the sediments. The total data set outlines a covariation between isotopic fractionation of hydrogen and oxygen.

kalic basaltic glass given by Nelson et al. (1986) to represent the basic glass components. Corresponding reactions can be expressed for the alteration of acidic glasses, which also will fractionate the hydrogen and oxygen isotopes similarly.

General mass constraints on reaction of this volcanic glass with initial seawater, combined with the stoichiometric coefficients of dissolved potassium, magnesium, and calcium, require both a magnesium and potassium sink. The product minerals of this alteration process are not well established, but Egeberg et al. (in press a) proposed that, in addition to chert, both a magnesium-rich smectite and a potassium zeolite are formed during the alteration process.

\section{Model Calculation}

Reaction 1 is constructed to account for the changes in porewater concentrations of potassium, calcium, and magnesium and to conserve iron in smectite.

$3 \mathrm{Si}_{50} \mathrm{Al}_{10} \mathrm{Fe}_{5} \mathrm{Ca}_{7} \mathrm{Mg}_{6} \mathrm{Na}_{3} \mathrm{KO}_{135}+21 \mathrm{Mg}^{2+}+7 \mathrm{~K}^{+}+11 \mathrm{Na}^{+}+183 \mathrm{H}_{2} \mathrm{O} \rightarrow$ $18 \mathrm{Na}_{0.33}\left(\mathrm{Mg}_{2.167} \mathrm{Fe}_{0.833}\right)\left(\mathrm{Al}_{0.33} \mathrm{Si}_{3.67}\right) \mathrm{O}_{10}(\mathrm{OH})_{2} \cdot 6 \mathrm{H}_{2} \mathrm{O}+$ $8\left(\mathrm{Na}_{0.58} \mathrm{~K}_{0.42}\right)_{3} \mathrm{Al}_{3} \mathrm{Si}_{5} \mathrm{O}_{16} \cdot 6 \mathrm{H}_{2} \mathrm{O}+21 \mathrm{Ca}^{2+}+18 \mathrm{H}^{+}+44 \mathrm{SiO}_{2}$ 

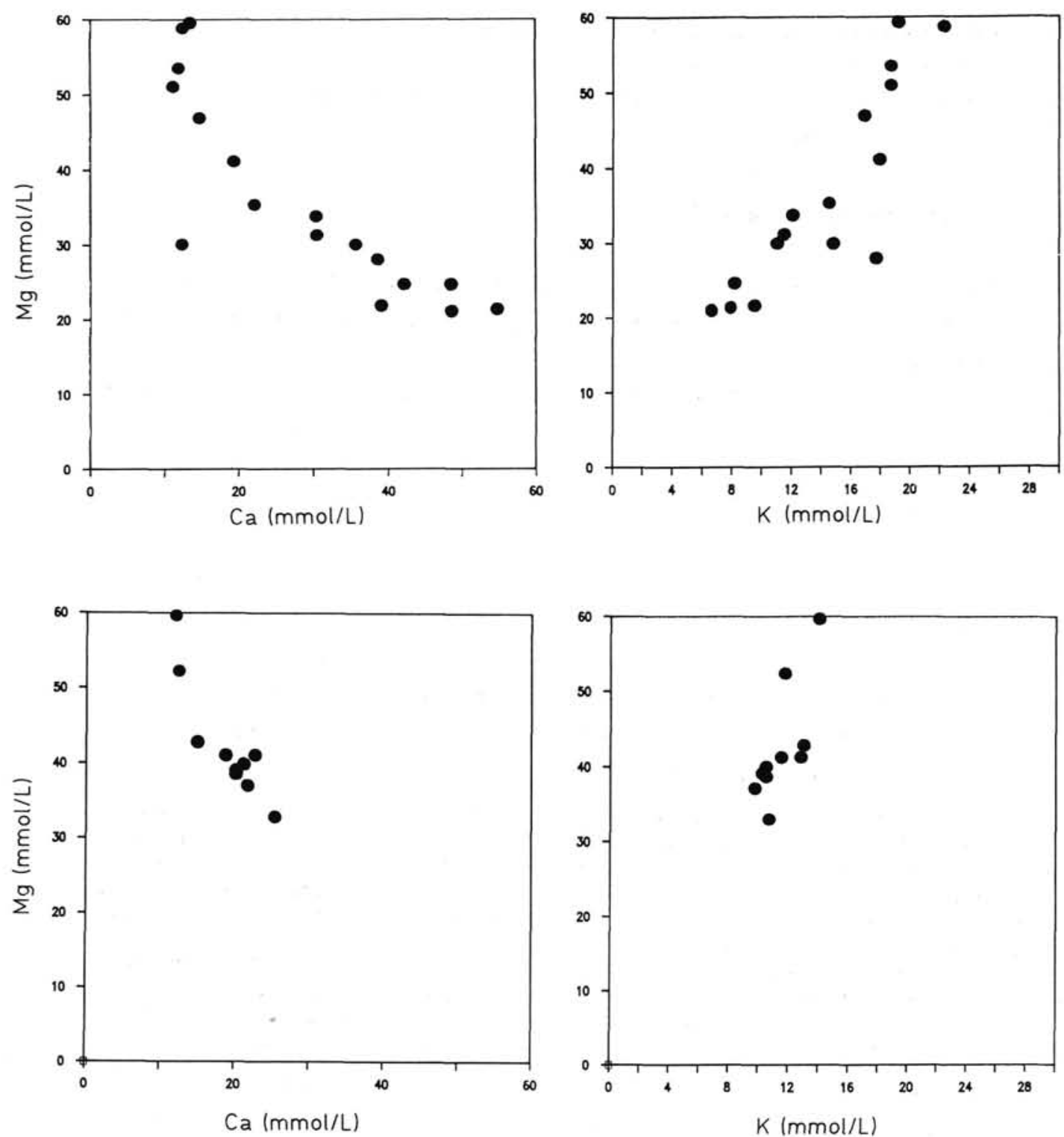

Figure 6. Correlation between dissolved constituents $(\mathrm{Mg}, \mathrm{Ca}$, and $\mathrm{K})$ of interstitial waters in ODP Leg 104 sediments. The decrease in magnesium is followed by a 1:1 increase in calcium, while the potassium decrease is about one third that of magnesium.

The composition of the trioctahedral smectite is taken as an endmember saponite (MacEwan and Wilson, 1980), and the composition of the zeolite is dictated by the stoichiometry of the reaction and the constraint imposed by conservation of aluminum. Excess silicon is precipitated as chert. Equation (1) is suitable for model calculations of the oxygen isotope distribution between the authigenic minerals and the pore water, as all the fractionation factors are known or can be reasonably estimated. The oxygen partition coefficients at $4^{\circ} \mathrm{C}$ and their temperature dependence are listed in Table 2 . The temperature-dependent fractionation factor of zeolites is represented by that of alkali feldspar, as was recommended by Lee (1987). Egeberg et al. (in press a) report results of nearly identical calculations. The most important feature is the very strong fractionation between pore water and the sum of all the authigenic minerals compared with previous studies (Lawrence et al., 1975; Perry et al., 1976), where only one product mineral was onsidered at a time. This is evident in Figure 7. In their ${ }^{18} \mathrm{O}$ budget calculations, Egeberg et al. (in press a) ignored the effect of isotope fractionation between free water and water held in interlayer positions in smectite and phillipsite. This has little effect on the ${ }^{18} \mathrm{O}$ budget but, as will be demonstrated below, reverses the trend for deuterium. The amount of interlayer water in smectite in reaction 1 is estimated based on water adsorption curves for trioctahedral smectites reported by Newman (1987).

Similar to Lawrence and Gieskes (1981), we adopt the idea that the interlayer water has an ice-like structure (Burst, 1976) and assume that it will concentrate ${ }^{18} \mathrm{O}$ to the same extent as ice. A closed system material balance employing the fractionation factors listed in Table 2 and a $\delta^{18} \mathrm{O}$ composition of volcanic glass of $8 \% 0$ (SMOW) (Taylor, 1968), shows that he observed shifts in pore water $\delta^{18} \mathrm{O}$ signatures could be brought about by alteration of less than $5 \%$ (volume) calc alkalic material. Thus we agree with Egeberg et al. (in press a) that the pore waters may evolve their chemical and ${ }^{18} \mathrm{O}$ composition without one having to invoke external sources or unreasonably large amounts of volcanic matter. Our own data and the data reported by Lawrence and Gieskes (1981) show that the negative trend of ${ }^{18} \mathrm{O}$ is usually 
Table 2. Stable isotope fractionation factors between minerals and waters.

\begin{tabular}{|c|c|c|c|}
\hline Mineral & $\begin{array}{l}1000 \ln \alpha \\
4{ }^{\circ} \mathrm{C}\end{array}$ & $\begin{array}{c}1000 \operatorname{Ln} \alpha=f(t) \\
f(t)\end{array}$ & Reference \\
\hline \multicolumn{4}{|c|}{ a) oxygen-16/oxygen-18 } \\
\hline Smectite & 29.9 & $2.67 * 10^{6} * T^{-2}-4.82$ & Yeh and Savin (1976) \\
\hline Chert & 36.9 & $3.09 * 10^{6} * \mathrm{~T}^{-2}-3.29$ & Knauth and Epstein (1976) \\
\hline Zeolite & 33. 4 & & Savin and Epstein (1970) \\
\hline Feldspar & 34.3 & $2.90 * 10 * T^{-2}-3.41$ & O'Neil and Taylor (1967) \\
\hline Ice $10 \circ$ & F) 3.0 & & o'Neil (1968) \\
\hline
\end{tabular}

b) hydrogen/deuterium

$\begin{array}{ll}\text { Smectite }-61.9 & \text { Savin and Epstein (1970) } \\ \text { Ice (0 ㅇ ) } 19.3 & 0 \text { Neil (1968) }\end{array}$

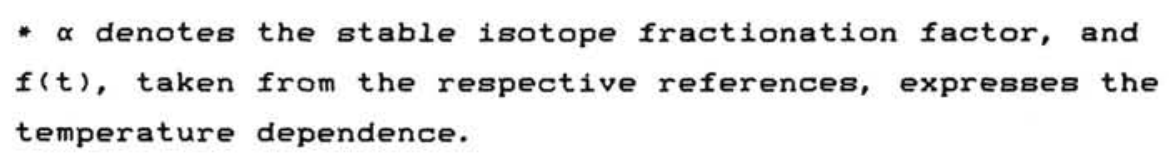

accompanied by a similar trend in deuterium anomalies. The hydroxyl groups in smectite are depleted in deuterium and, neglecting other effects, reaction 1 would give rise to positive porewater deuterium signatures. However, if interlayer water fractionates deuterium similar to its fractionation of ice, mass balance calculations using the fractionation factors listed in Table 2 show that the pore water will evolve toward negative deuterium signatures. The shift is only about one third of that for oxygen, thus the amount of structured water given by reaction 1 is too small to accomplish the observed shifts.

\section{CONCLUSIONS}

The alteration of volcanic matter is most probably responsible for the variation observed in major elements and isotopic composition of interstitial waters of ODP Leg 104 sediments. The working hypothesis is is that volcanic glass within the sediments reacts with the pore water of initial seawater composition. All changes in pore-water composition (except $\delta \mathrm{D})$ can be accounted for by this model. However, diffusive/advective transport within the sediments cannot totally be excluded. Our findings and conclusions can be summarized as:

1. The ${ }^{87} \mathrm{Sr} /{ }^{86} \mathrm{Sr}$ ratios are considerably below those of contemporaneous seawater; volcanic matter is the only candidate as source for that light strontium.

2. Based on the observed change in major element composition of the pore water, we have proposed (Egeberg et al., in press a) a diagenetic reaction where volcanic glass reacts with pore-water magnesium and potassium and forms trioctahedral smectite, phillipsite, and chert.

3. Model calculations of the isotopic fractionation of oxygen match the observed trend of decreasing $\delta^{18} \mathrm{O}$ with increasing depth. We have not, however, been able to model the isotopic fraction of hydrogen; and this problem noted by Lawrence and Gieskes (1981) remains unsolved.
The isotopic model calculation demonstrates that the alteration of less than 5 volume percent volcanic glass is required to account for the observed $\delta^{18} \mathrm{O}$ shift. No external sources are then needed (Lawrence et al., 1977). Disseminated volcanic glasses in the sediments are the likely solid reactants.

\section{ACKNOWLEDGMENTS}

We would like to thank the crew and shipboard scientists for providing us with the interstitial water samples. We are indebted to Marit Vadset and Ingar Johansen for technical assistance. We gratefully acknowledge critical review by Bjorn Buchardt and the help and guidance of Elliott Taylor and Olav Eldholm.

\section{REFERENCES}

Burst, J. F., 1976. Argillaceous sediment dewatering. Ann. Rev. Earth Planet. Sci., 4: 293-318.

DePaolo, D., 1986. Detailed record of the Neogene $\mathrm{Sr}$ isotopic evolution of seawater from DSDP Site 590B. Geology, 14: 103-106.

Egeberg, P. K., Aagaard, P., and Smalley, P. C., in press a. Major element and oxygen isotope studies of interstitial waters: ODP Leg 113. In Barker, P. F., Kennett, J. P., O'Connell, S., et al., Proc. ODP, Sci. Res., 113: College Station, TX (Ocean Drilling Program).

Egeberg, P. K., Smalley, P. C., and Aagaard, P., in press b. Strontium isotope geochemistry of Leg 113 interstitial waters and carbonates. In Barker, P. F., Kennett, J. P., O'Connell, S., et al., Proc. ODP, Sci. Res., 113: College Station, TX (Ocean Drilling Program).

Elderfield, H., and Gieskes, J. M., 1982. Sr isotopes in intertitial waters of marine sediments from Deep Sea Drilling Project cores. Nature, 300: 493-497.

Eldholm, O., Thiede, J., Taylor, E., et al., 1987. Proc. ODP, Init. Repts., 104: College Station, TX (Ocean Drilling Program).

Gieskes, J. M., Lawrence, J. R., and Galleisky, G., 1978. Interstitial water studies Leg 38. In Talwani, M., Udintsev, G., et al., Init. Repts. DSDP, Suppl. to Vols. 38, 39, 40, and 41: Washington (U.S. Govt. Printing Office), 121-133.

Hawkesworth, C. J., and Elderfield, H., 1987. The strontium isotope composition of interstitial waters from Site 245 and 336, DSDP. Earth Planet. Sci. Lett., 40: 423-432. 
Knauth, L., and Savin, S., 1976. Hydrogen and oxygen isotope ratios in modular and bedded cherts. Geochim. Cosmochim. Acta, 40: 10951108.

Lawrence, J. R., Gieskes, J. M., and Broecker, W. S., 1975. Oxygen isotope and cation composition of DSDP pore waters and the alteration of layer II basalts. Earth Planet. Sci. Lett., 27: 1-10.

Lawrence, J. R., and Gieskes, J. M., 1981. Constraints on water transport and alteration in the oceanic crust from the isotopic composition of pore water. J. Geophys. Res., 86: 7924-7934.

Lee, Y. I., 1987. Isotopic aspects of thermal and burial diaenesis of sandstones at DSDP Site 445, Daito Rise, Northwest Pacific Ocean. Chem. Geol., 65: 95-102.

MacEwan, D.M.C., and Wilson, M. J., 1980. Interlayer and intercalation complexes of clay minerals. In Brindley, G. W., and Brown, G. (Eds.), Crystal structures of clay minerals and their X-ray identification: London (Mineralogical Society), 197-248.

Manheim, F. T., and Sayles, F. L., 1974. Composition and origin of interstitial waters of marine sediments based on deep sea drill cores. In Goldberg, E. D. (Ed.), The Sea (Vol. 5): New York (Wiley Interscience), 527-568.

Nelson, P. C., Froggatt, P. C., and Gosson, G. J., 1986. Nature, chemistry, and origin of late Cenozoic megascopic tephras in Leg 90 cores from the Soutt west Pacific. In Kennett, J. P., von der Borch, C. C., et al., Init. Repts. DSDP, 90: Washington (U.S. Govt. Printing Office), 1161-1173.

Newman, A.C.D., 1987. Chemistry of clays and clay minerals: London (Longman Scientific and Technical).

O'Neil, J. R., and Taylor, H. P., 1967. The oxygen isotope and cation exchange chemistry of feldspars. Am. Mineral., 52: 1414-1437.

O'Neil, J. R., 1968. Hydrogen and oxygen Isotope fractionation between ice and water. J. Phys. Chem., 72: 3683-3684.
Perry, E. A., Gieskes, J. M., and Lawrence, J. R., 1976. Mg, Ca, and $\mathrm{O}^{18} / \mathrm{O}^{16}$ exchange in the sediment-pore water system, Hole 149 , DSDP. Geochim. Cosmochim. Acta, 40: 413-423.

Savin, S. M., and Epstein, S., 1970. The oxygen and hydrogen isotope geochemistry of ocean sediments and shales. Geochim. Cosmochim. Acta, 34: 43-63.

Shipboard Scientific Party, 1987a. Site 642. In Eldholm, O., Thiede, J., Taylor, E., et al., Proc. ODP, Init. Repts, 104: College Station, TX (Ocean Drilling Program).

Shipboard Scientific Party, 1987b. Site 643. In Eldholm, O., Thiede, J., Taylor, E., et al., Proc. ODP, Init. Repts, 104: College Station, TX (Ocean Drilling Program).

Shipboard Scientific Party, 1987c. Site 644. In Eldholm, O., Thiede, J., Taylor, E., et al., Proc. ODP, Init. Repts, 104: College Station, TX (Ocean Drilling Program).

Staudigel, H., and Hart, S. R., 1985. Dating of ocean crust hydrothermal alteration: strontium isotope ratios from Hole 504B and a reinterpretation of $\mathrm{Sr}$ isotope data from Deep Sea Drilling Project Sites 105, 232, 417 and 418. In Anderson, R. N., Honnore, J., et al., Init. Rpts. DSDP, 83: 297-303.

Taylor, H. P., 1968. The oxygen isotope geochemistry of igneous rocks. Contr. Mineral. Petrol., 19: 1-17.

Yeh, H. W., and Savin, S. M., 1976. The extent of oxygen isotope exchange between clay minerals and sea water. Geochim. Cosmochim. Acta, 40: 743-748.

Date of initial receipt: 14 March 1988

Date of acceptance: 4 June 1988

Ms 104B-122 

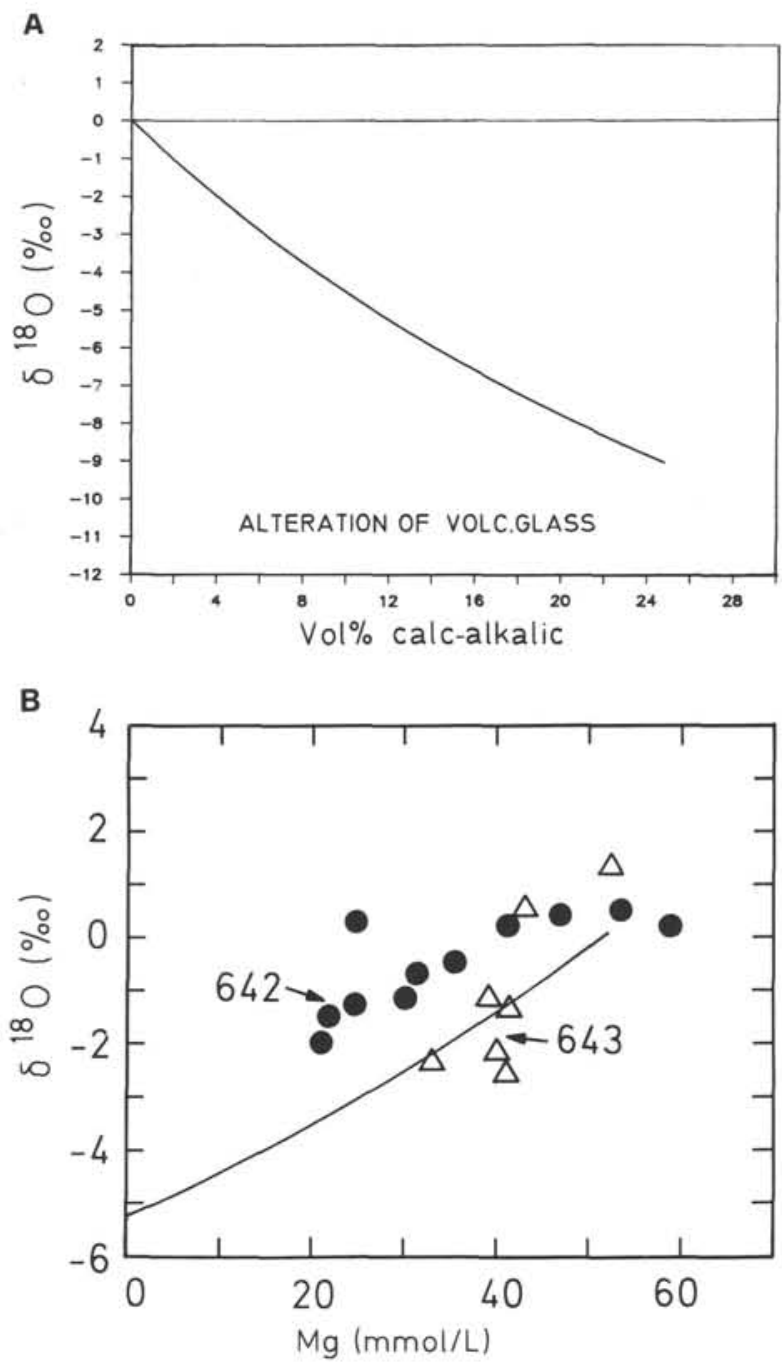

Figure 7. Isotopic model calculation of the alteration of volcanic glass to smectite, phillipsite, and chert according to equation (1) (see text). A: Alteration of only $5 \%$ (volume) of volcanic glass is needed to explain the observed shift in oxygen isotopes. B: Calculated oxygen shift as a function of magnesium depletion of the pore water, compared with observed values. 